\title{
Evaluation of Aluminum Chloride As an Effective Short-Term Solution for Reducing Odor - Causing Volatile Fatty Acids in Duck Litter
}

-Author(s)
Chung TH'
Park JH"
Kim CM"I'
Choi IH'
| Department of Companion Animal \&
Animal Resources Science, Joongbu
University, Geumsan-gun, 32713, South
Korea
" Department of Environmental Engineering,
Gyeongnam National University of Science
and Technology, Jinju, 52725, Korea
II Division of Science Education, Chemistry
Education Major, Daegu University,
Gyeongsan, 38453, South Korea

Tae Ho Chung and Jeong Ho Park contributed equally to this work as first author

\section{nMail Address}

Corresponding author e-mail address In Hag Choi

Department of Companion Animal \& Animal Resources Science, Joongbu University,

Geumsan-gun, 32713, South Korea

Tel: $\quad+82-41-750-6284$

Email: wicw@chol.com

\section{aKeywords}

Aluminum chloride, $\mathrm{pH}$, volatile fatty acids, duck litter.

\section{ABSTRACT}

This study evaluated the effects of aluminum chloride $\left(\mathrm{AlCl}_{3}\right)$ on $\mathrm{pH}$ and volatile fatty acid levels in duck litter over the course of a three-week experimental period. Ninety one-day-old Pekin ducks (45 males and 45 females) were distributed into three treatments with three replicates each (10 ducks per replicate) using a completely randomized design. Two treatments were top-dressing duck litter with thin layers $(1-2 \mathrm{~cm})$ of $50 \mathrm{~g}$ or $100 \mathrm{~g}$ of $\mathrm{AlCl}_{3}$ per $\mathrm{kg}$ of litter, respectively; the control group received no litter treatment. Although no significant differences in propionic acid levels ( $p>0.05$ ) were observed in any of the treatments, overall $\mathrm{pH}$ values for the $50 \mathrm{~g}$ and $100 \mathrm{~g} \mathrm{AlCl}_{3}$ treatments were both lower $(p<0.05)$ than those of the control group. Additionally, the two $\mathrm{AlCl}_{3}$ treatments revealed a corresponding influence $(p<0.05)$ on acetic acid levels during the last two weeks of the experimental period. These results indicate that aluminum chloride amendments (at a suggested rate of $100 \mathrm{~g}$ per $\mathrm{kg}$ of duck litter) are potentially useful in lowering the $\mathrm{pH}$ of duck litter, thereby decreasing acetic acid production as an indicator of odor emissions.

\section{INTRODUCTION}

Odors associated with livestock and poultry operations are primarily generated from the uncontrolled anaerobic decomposition of waste products, such as animal manure and litter (Williams et al., 2013). These materials contain many macronutrients, including carbohydrates, proteins, and lipids, which bacteria readily consume. As manure and litter decompose, some 80 to 200 different odorous compounds may be produced (Williams et al., 2013). According to Choi et al. (2011), the primary odorants found in animal manure result from the presence of volatile fatty acids (VFAs), mercaptans (thiols), esters, carbonyls, aldehydes, alcohols, and amines. Although VFAs often result from the fermentation of carbohydrates (sugars, starch, and cellulose), undigested carbohydrates excreted in the feces may also continue to ferment, forming a variety of VFA compounds (including acetic, propionic, and butyric acids). Thus, incomplete degradation not only serves as a catalyst for VFA production, but also promotes the development of many of the most predominant odor-causing compounds associated with livestock and poultry operations (Rahman et al., 2008).

Although some studies have considered VFAs to be among the most significant causative factors of livestock and poultry production odor, their levels may be reduced suing several alternative approaches, including the use of litter amendments. The effectiveness of such strategies varies widely depending on the amendment types selected; however, aluminum sulfate [alum, $\left.\mathrm{Al}_{2} \mathrm{SO}_{4}\right)_{3}$ ] and aluminum chloride $\left(\mathrm{AlCl}_{3}\right)$ have been proven to be especially effective in reducing ammonia content and decreasing the overall production of odor compounds 
Evaluation of Aluminum Chloride As an Effective Short-Term Solution for Reducing Odor-Causing Volatile Fatty Acids in Duck Litter associated with poultry litter and swine manure (Smith et al., 2004; Moore et al., 2006). In addition to odorant reduction, related advantages of such approaches include economic benefits and improved health of both farmed animals and humans who consume their products. Although litter amendments are currently applied to agricultural lands to improve crop production and serve as valuable resources to reduce odors associated with farm operations, little new information on the specific impact of aluminum chloride $\left(\mathrm{AlCl}_{3}\right)$ amendments on duck litter odor is available. Thus, the objective of this study was to evaluate the effects of the addition of $\mathrm{AlCl}_{3}$ on duck litter on litter $\mathrm{pH}$ levels and VFA production for a short time period.

\section{MATERIALS AND METHODS}

\section{Experimental design and birds}

\section{Experimental design}

Protocols for this experiment were carried out in accordance with the guidelines of with the Gilhong Farm Committee for Animal Care and Policy (Geochang, South Korea).

Over a three-week experimental period, 90 oneday-old Pekin ducks (45 males and 45 females) were distributed into three chemical treatments of three replicates each, with 10 ducks ( 5 males and 5 females) per replicate, using a completely randomized design. Each pen $(2.5 \times 2 \mathrm{~m})$ was equipped with one tube feeder and six nipple drinkers. An 8-cm thick reused litter (six flocks, a mixture of sawdust and rice hull) was added to each pen. Feed and water were provided ad libitum throughout the experimental period. Ducks were fed a commercial diet formulated for the starter period, including $21 \%$ crude protein and 2,900 kcal of $\mathrm{ME} / \mathrm{kg}$. To control litter humidity and microbiological processes, ventilation and temperatures in the duck houses were regulated by an automatic environmental control system.

\section{Chemical treatment and duck litter sampling}

Aluminum chloride $\left(\mathrm{AlCl}_{3} \cdot 6 \mathrm{H}_{2} \mathrm{O}\right)$ was obtained from the Samchun Chemicals Company (Pyeongtaek, South Korea). Treatments consisted of the top-dressing of litter with thin layers (1-2 cm deep) of duck litter with $\mathrm{AlCl}_{3}$ at rates of $50 \mathrm{~g}$ and $100 \mathrm{~g}$ per $\mathrm{kg}$ of litter; no litter amendment was applied in control treatment.

Duck litter sampling was carried out according to protocols of the method employed by Choi \& Moore
(2008). Three samples of each litter treatment were obtained at four random sites inside each pen at weekly intervals over a period of three weeks. At each collection time, samples were picked up using a gloved hand and mixed thoroughly. In order to avoid crosscontamination of the samples, one glove per sample was used. The collected samples, each weighing approximately $100 \mathrm{~g}$, were placed in individual plastic bags and sealed as quickly as possible. The sealed bags were immediately refrigerated under $4{ }^{\circ} \mathrm{C}$ for one day, and then submitted to the laboratory for $\mathrm{pH}$ and volatile fatty acid analyses.

\section{Analyses of $\mathrm{pH}$ and volatile fatty acid}

In order to determine $\mathrm{pH}, 10 \mathrm{~g}$ samples of duck litter were extracted with $100 \mathrm{~mL}$ of deionized water for 2 h using a mechanical shaker, and then centrifuged at $3,000 \mathrm{rpm}$ for 10 minutes. Aliquots of the supernatant were taken for $\mathrm{pH}$ and VFA (acetic acid, propionic acid, butyric acid, isobutyric acid, valeric acid, and isovaleric acid) level determinations. Overall pH was measured directly on unfiltered samples using a $\mathrm{pH}$ meter (Metrohm/Brinkmann 691, ALT, Connecticut, USA), as proposed by Choi \& Moore (2008). Samples for VFA determination were centrifuged at 10,000 rpm for $10 \mathrm{~min}$, and then the resulting supernatant was filtered and transferred to autosampler vials. VFA determination was measured using a Hitachi L7485 High Performance Liquid Chromatograph with a UV detector (Spectroflow 757, ABI Analytical Kratos Division, Ramsey, USA).

\section{Statistical Analysis}

Statistics were calculated using one-way analysis of variance (ANOVA) applying the general linear model procedure of SAS (SAS Institute Inc., 2002). The duck holding pen was defined as the experimental unit, and sets of means were compared for significance $(p<0.05)$ using Duncan's new multiple range test (Duncan, 1955).

\section{RESULTS AND DISCUSSION}

\section{pH}

The effects of the $\mathrm{AlCl}_{3}$ treatments on litter $\mathrm{pH}$ levels are indicated in Fig. 1. In the control group, $\mathrm{pH}$ values remained above 8.0, ranging from 8.39 (week 1) to 8.22 (week 3 ). The pH values obtained in the 50 $\mathrm{g}$ and $100 \mathrm{~g} \mathrm{AlCl}_{3}$ treatments varied between 6.41 and 8.08 and were both lower $(p<0.05)$ than those of the control group. Between the two $\mathrm{AlCl}_{3}$ treatments, the 
$100 \mathrm{~g}$ treatment, which $\mathrm{pH}$ ranged from 6.41 (week 1) to 7.30 (week 3) promoted the greatest reduction in overall litter $\mathrm{pH}$. This notable reduction in $\mathrm{pH}$ levels may be explained by the fact that $\mathrm{AlCl}_{3}$ acts as an acidifier, creating acidic conditions in the duck litter. Smith et al. (2001) reported that similar reductions in the $\mathrm{pH}$ of swine manure with alum and aluminum chloride amendments are expected to occur because of hydrolysis. In other words, as $\mathrm{Al}^{3+}$ ions react with the solution (in this case, manure), hydrolysis leads to the formation of $\mathrm{Al}(\mathrm{OH})_{3}$, which releases $3 \mathrm{H}^{+}$ions to the solution, creating acidic conditions and thereby reducing overall manure $\mathrm{pH}$ (Smith et al., 2004). Comparably, Varel \& Miller (2004) have also suggested that thymol and eugenol treatments in stored cattle waste may be useful for reducing manure $\mathrm{pH}$ due to the presence of similar chemical reactions.

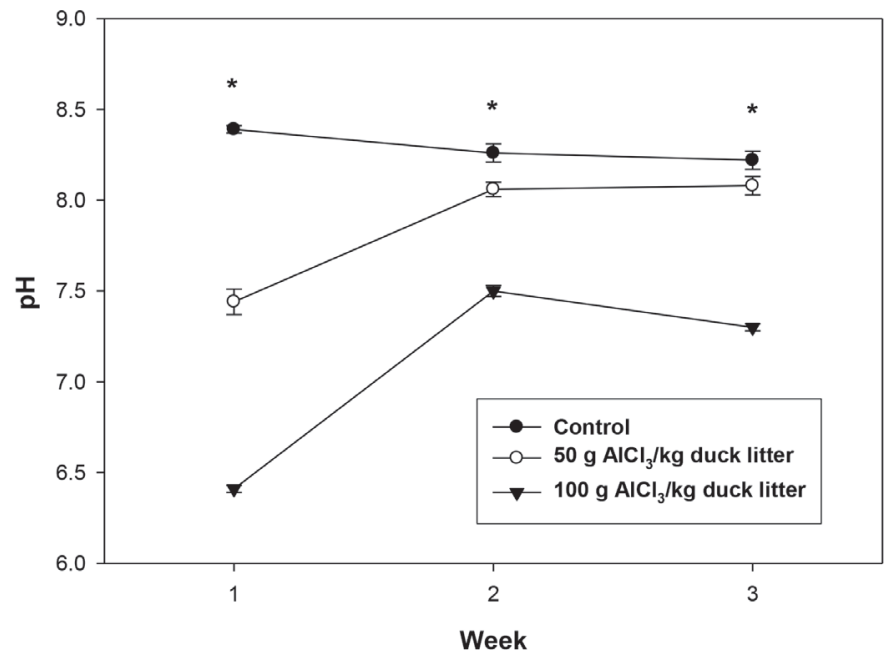

Figure 1 - Effect of aluminum chloride amendments on duck litter pH during the experimental period. The vertical bars represent the standard error of the mean values. * indicates significant differences at $p<0.05$.

\section{Volatile fatty acid (VFA)}

Fig. 2 shows the effects of $\mathrm{AlCl}_{3}$ treatments on both acetic acid and propionic acid production during the three-week experimental period. Among VFA, butyric acid, isobutyric acid, valeric acid and isovaleric acid were not detected in the litter. The treatment of duck litter with $\mathrm{AlCl}_{3}$ amendments significantly influenced $(p<0.05)$ litter acetic acid production during the last two weeks of the study; no influence was noted, however, during the first week of the experiment. Initial acetic acid readings for the control group were $0.00 \%$ during week 1 , and then ranged from $0.21 \%$ to $0.60 \%$ during weeks 2 and 3 . Acetic acid values in the $50 \mathrm{~g}$ and $100 \mathrm{~g} \mathrm{AlCl}_{3}$ treatments were both almost $0.00 \%$ during week 1 , then increased during week 2 to $0.20 \%$ and $0.03 \%$, respectively. By week 3 , acetic acid levels were $0.20 \%$ for the $50 \mathrm{~g} \mathrm{AlCl}_{3}$ treatments and $0.09 \%$ for the $100 \mathrm{~g} \mathrm{AlCl}_{3}$ treatments. Conversely, no significant differences in propionic acid $(p>0.05)$ were found in any of the treatments, which varied from $0.00 \%$ to $10.27 \%$ throughout the experimental period. Overall, propionic acid levels tended to decrease both in the $50 \mathrm{~g}$ (ranging from $0.00 \%$ to $6.44 \%$ ) and $100 \mathrm{~g}$ treatments (ranging from $0.03 \%$ to $1.17 \%$ ) as compared to the control group.
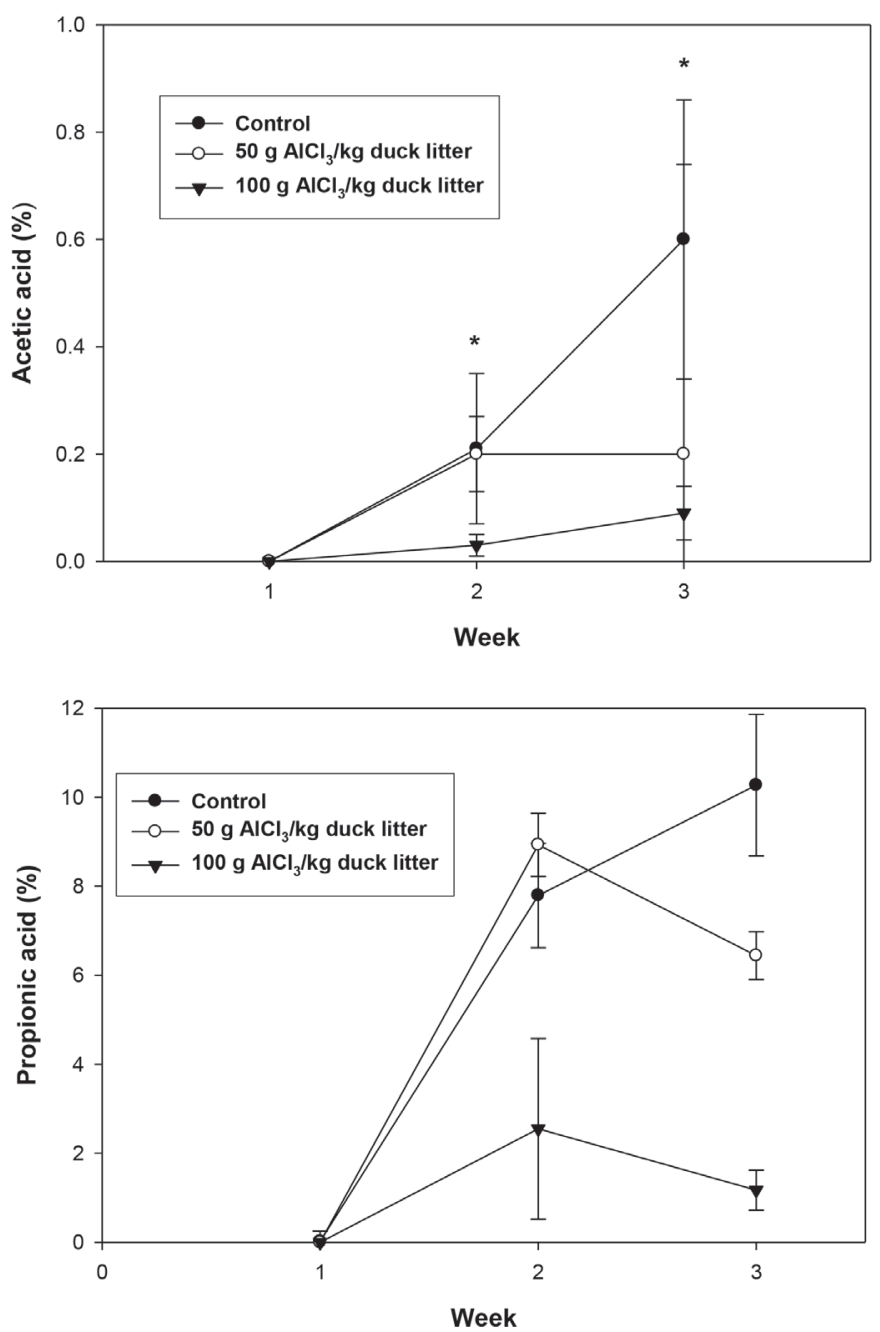

Figure 2 - Effect of aluminum chloride amendments on duck litter acetic acid and propionic acid levels during the experimental period. The vertical bars represent the standard error of the mean values. ${ }^{*}$ indicates significant differences at $p<0.05$.

These results not only indicate that the use of $\mathrm{AlCl}_{3}$ was effective at controlling odor production in duck litter, but also support similar findings by Varel \& Miller (2004), who showed that microbial activity was suppressed by the addition of eugenol to cattle waste. Such treatments are capable of preventing the production of the short-chain VFAs most frequently implicatedasthe predominantodor-causing compounds produced by livestock wastes; relative VFA reductions can thus be directly correlated with lower pH levels in 
duck litter due to the use of $\mathrm{AlCl}_{3}$ amendments (Choi \& Moore, 2008). Reduction of acetic and propionic acid production and/or fermentation activity, as indicated by $\mathrm{pH}$ data ranges between 6.41 and 7.30 for the 100 $\mathrm{g} \mathrm{AlCl}_{3}$ amendment, also seemed to be more effective than those produced by the $50 \mathrm{~g} \mathrm{AlCl}_{3}$ treatments.

\section{CONCLUSION}

The results of the present study indicate that acetic acid (VFA) and pH levels of the litter were reduced with aluminum chloride litter amendments. In particular, the $\mathrm{AlCl}_{3}$ amendment at a level of $100 \mathrm{~g}$ per $\mathrm{kg}$ of duck litter was shown to have the most positive impact in reducing odor emissions. These results support duck litter amendment with $\mathrm{AlCl}_{3}$ at $100 \mathrm{~g} / \mathrm{kg}$ of litter as a best management practice in the duck industry that not only aid producers to reduce VFA levels, but also show that it is beneficial to the environment.

\section{ACKNOWLEDGEMENTS}

This work was carried out with the support of "Cooperative Research Program for Agriculture Science

\& Technology Development (Project title: Functional feed material development and efficacy evaluation for detector dog's ability improvement, Project No: PJ01198902)" Rural Development Administration, Republic of Korea.

\section{REFERENCES}

Choi IH, Moore PAJr. Effect of liquid aluminum chloride additions to poultry litter on broiler performance, ammonia emissions, soluble phosphorus, total volatile fatty acids, and nitrogen contents of litter. Poultry Science 2008;87:1955-1963.

Choi IH, Choi JH, Ko SH, Moore PAJr. Reducing ammonia emissions and volatile fatty acids in poultry litter with liquid aluminum chloride. Journal of Environmental Science Health Part B 2011;46:432-435.

Duncan DB. Multiple range and multiple F-test. Biometrics 1955;11:1-42.

Moore PAJr, Joem BC, Edwards DR, Wood CW, Daniel TC. Effects of manure amendments on environmental and production problems. In: Rice JM, Caldwell DF, Humenik FJ, editors. Animal agriculture and environment: national center for manure and animal waste management white papers. St Joseph: ASABE; 2006. p.759-776.

Rahman S, Mukhtar S, Wiederholt R. Managing odor nuisance and dust from cattle feedlots. Fargo: North Dakota State University; 2008.

SAS Institute. SAS/STAT user's guide. Version 8.2. Cary: SAS Institute; 2002.

Smith DR, Moore PAJr, Griffis CL, Daniel TC, Edwards DR, Boothe DL. Effects of alum and aluminum chloride on phosphorus runoff from swine manure. Journal of Environmental Quality 2001;30:992-998.

Smith DR, Moore PAJr, Haggard BE, Maxwell CV, Daniel TC, VanDevander $\mathrm{K}$, et al. Effect of aluminum chloride and dietary phytase on relative ammonia losses from swine manure. Journal of Animal Science 2004;82:605-611.

Varel VH, Miller DL. Eugenol stimulates lactate accumulation yet inhibits volatile fatty acid production and eliminates coliform bacteria in cattle and swine waste. Journal of Applied Microbiology 2004;97:10011005

Williams MP, Coufal C, Caraway E, Carpenter R, Lee JT. Evaluation of a rice/soy fermentate on performance and volatilization of odorants from fresh fecal material when included in broiler diets. International Journal of Poultry Science 2013;12:698-704. 